\title{
Analisis Pengaruh Curah Hujan dan Kecepatan Angin Terhadap Konstruksi Papan Reklame Single Pole Tipe Sumbu Tengah
}

\author{
Norman Iskandar*, Wahyu Damarjati, M.S.K. Tony Suryo Utomo \\ Departemen Teknik Mesin, Fakultas Teknik, Universitas Diponegoro \\ Jl. Prof. Sudarto, SH - Tembalang, Semarang 50275 Telp. (024) 7460059 \\ *E-mail: norman.undip@gmail.com
}

\begin{abstract}
Cases of billboards collapsing are still quite common. The inability to withstand the burden is thought to be the cause. This is the reason for the need to review security standards that have been determined by the government as the party authorized to give permission. In this article, we will discuss the results of the analysis of billboards that have been given permission to be installed by the Semarang city government with FEM-based software simulation methods. The analyzed billboards have a size of $4 x$ $6 \mathrm{~m}$ with a schedule 40 steel pipe with a 12inch diameter as support, elbow steel $40 \times 40 \times 4 \mathrm{~mm}$ as a truss structure, and galvanized steel plate with an area of $4 \times 6 \mathrm{~m}$ as thick as $0.2 \mathrm{~mm}$. Wind speed and rainfall data used are sourced from the BMKG of Semarang City, with variations in wind speed of 15 $\mathrm{m} / \mathrm{s}, 25 \mathrm{~m} / \mathrm{s}$ and the volume of rainfall is $736 \mathrm{~mm} /$ day. From the simulation results obtained a maximum stress value of $1.025 \times 108 \mathrm{~Pa}$ at wind speeds of $15 \mathrm{~m} / \mathrm{s}$, and $2.754 \times 108 \mathrm{~Pa}$ at wind speeds of $25 \mathrm{~m} / \mathrm{s}$ for loading conditions in the form of wind. While the maximum stress value is $1.029 \times 108 \mathrm{~Pa}$ at wind speeds of $15 \mathrm{~m} / \mathrm{s}$, and $2.762 \times 108 \mathrm{~Pa}$ at wind speeds of $25 \mathrm{~m} / \mathrm{s}$ for a combination of wind loads and rainfall. The two maximum stress values are still below the yield strength of the structure forming material, which is $235 \mathrm{MPa}$. So that the structure is safely used in these loading conditions. But at a speed of $25 \mathrm{~m} / \mathrm{s}$, the maximum stress is at \pm 30 Mpa above yield strength, meaning that the structure is not safe if it experiences such a large load continuously and is risky by fatigue stress. The force due to rainwater in the structure is not too significant. The magnitude of the difference in force between the rain drag force and the water drag force and rain is always smaller than $50 \mathrm{~N}$. So for general calculations, the magnitude of the force due to rainwater can be neglected.
\end{abstract}

Keywords: Billboards, FEM, von Mises, rainfall, wind speed

\section{Abstrak}

Kasus robohnya papan reklame masih cukup sering terjadi. Ketidakmampuan menahan beban diduga menjadi penyebabnya. Hal ini menjadi alasan perlunya dikaji ulang standarisasi keamanan yang telah ditentukan oleh pemerintah selaku pihak yang berwenang memberikan ijin. Pada artikel ini akan dibahas tentang hasil analisis terhadap papan reklame yang telah diberikan ijin untuk dipasang oleh pemerintah Kota Semarang dengan metode simulasi software berbasis FEM. Papan reklame yang dianalisis berukuran $4 \times 6$ m dengan pipa baja schedule 40 berdiameter 12in sebagai penumpu, baja siku 40 × 40 x 4 mm sebagai struktur truss, dan plat baja galvanis dengan luas 4 × 6 m setebal 0,2 mm. Data kecepatan angin dan curah hujan yang digunakan bersumber dari BMKG Kota Semarang, dengan variasi kecepatan angin adalah $15 \mathrm{~m} / \mathrm{s}, 25 \mathrm{~m} / \mathrm{s}$ dan volume curah hujan adalah $736 \mathrm{~mm} /$ hari. Dari hasil simulasi didapatkan nilai stress maksimal $1,025 \times 10^{8}$ Pa pada kecepatan angin $15 \mathrm{~m} / \mathrm{s}$, dan $2,754 \times 10^{8}$ $\mathrm{Pa}$ pada kecepatan angin $25 \mathrm{~m} / \mathrm{s}$ untuk kondisi pembebanan berupa angin. Sedangkan nilai stress maksimal $1,029 \times 10^{8} \mathrm{~Pa}$ pada kecepatan angin $15 \mathrm{~m} / \mathrm{s}$, dan $2,762 \times 10^{8} \mathrm{~Pa}$ pada kecepatan angin 25 $\mathrm{m} / \mathrm{s}$ untuk kombinasi beban angin serta curah hujan. Kedua nilai tegangan maksimum masih dibawah yield strength dari material pembentuk struktur, yaitu $235 \mathrm{MPa}$. Sehingga struktur aman digunakan pada kondisi pembebanan tersebut. Namun pada kecepatan $25 \mathrm{~m} / \mathrm{s}$, tegangan maksimum berada pada $\pm 30 \mathrm{Mpa}$ diatas yield strength, artinya struktur tidak aman apabila mengalami beban sebesar itu secara terus menerus dan riskan oleh tegangan fatigue. Gaya akibat air hujan pada struktur tidak terlalu signifikan. Besarnya selisih gaya antara gaya drag hujan dengan gaya drag air dan hujan selalu lebih kecil dari 50 N. Sehingga untuk perhitungan secara umum, besarnya gaya akibat air hujan bisa diabaikan.

Kata kunci: Papan reklame, FEM, von Mises, curah hujan, kecepatan angin

\section{Pendahuluan}

Papan reklame atau billboard merupakan salah satu bentuk media promosi diluar ruangan. Papan reklame biasa digunakan sebagai saranan kampanye, himbauan sosial atau sebagai sarana membujuk calon konsumen terkait 
penjualan produk barang atau jasa. Ciri khas papan reklame adalah bentuknya yang besar dan tinggi serta biasa dipasang dilokasi ramai dan strategis.

Papan reklame memiliki rentang ukuran dari yang kecil $(1 \times 2 \mathrm{~m})$ hingga besar $(5 \mathrm{x} 10 \mathrm{~m})$. Ukuran papan reklame yang semakin besar juga meningkatkan resiko terjadinya papan reklame roboh semakin besar, mengingat penempatan papan reklame sendiri berada diluar ruangan (outdoor). Hal Ini tentu bisa menimbulkan kerugian jiwa dan materi. Terhitung dari tahun 2012 s/d tahun 2014 terjadi beberapa kasus robohnya reklame ditanah air. Pada tanggal 16 Maret 2012 sebuah papan reklame berukuruan 6x4m roboh menimpa sebuah warnet didaerah Jl Teuku Umar Semarang di depan kantor PT PLN (Persero) Distribusi Jateng dan DIY [1]. Pada tanggal 14 Maret 2013 terjadi kembali di Kota Bandung sebuah reklame berukuran 5x10m roboh [2]. Pada tanggal 20 April 2014 didaerah Jakarta Barat sebuah baliho roboh menipa pengendara bermotor [3]. Bahkan ditahun 2016 tercatat beberapa kasus papan reklame roboh diberbagai daerah seperti Jakarta, Palembang, dan Jawa Tengah. Sebagai langkah pencegahan maka pembuatan dan pemasangan reklame harus diperhitungkan dengan matang sehingga faktor keamanan terjamin [4].

Kerusakan dan kegagalan struktur papan reklame besar akibat angin topan atau jenis angin kencang lainnya telah sering dijadikan bahan kajian di berbagai wilayah dan belahan dunia [5,6]. Kerusakan pada papan reklame dapat dikategorikan menjadi tiga tipe yaitu kerusakan pada pelat/papan, kerusakan pada struktur penopang dan kerusakan keseluruhan struktur akibat kegagalan pada pondasi [7, 8, 9]. Kasus kerusakan yang sering terjadi adalah karena kerusakan pada tiang penyangga, maka perlu dikaji ulang standarisasi yang dibuat oleh Pemerintah karena mereka yang berhak memberikan ijin pengadaan papan reklame diwilayahnya. Kinerja sistem struktur papan reklame dapat dievaluasi dengan mempertimbangkan respon searah angin dan respon torsional, sedangkan respons pada arah angin melintang dapat diabaikan [9].

Tujuan dari kajian ini adalah untuk melakukan konfirmasi perhitungan pembebanan menggunakan Metode Elemen Hingga, pada salah satu tipe papan reklame yang dimiliki oleh sebuah perusahaan advertising dan telah mendapatkan ijin dari PEMKOT Semarang.

\section{Material dan metode penelitian}

Metodologi yang digunakan dalam penelitian ini adalah dengan metode simulasi dengan menggunakan software ANSYS FLUENT dan SolidWork. Parameter kecepatan angin maksimum dari data kecepatan angin selama periode 2011-2015 adalah 15 m/s menurut BMKG Kota Semarang dan 25 m/s untuk kecepatan angin minimum sesuai standar pembangunan Indonesia [10]. ANSYS FLUENT digunakan untuk mensimulasikan gaya drag akibat angin dan hujan angin dari kedua parameter kecepatan angin. Hasil simulasi tersebut kemudian diaplikasikan ke struktur menggunakan SolidWork untuk mengetahui besarnya tegangan, regangan, dan displacement dari struktur akibat pembebanan angin dan hujan angin, sehingga diperoleh tegangan maksimum yang diperbolehkan, besarnya nilai keamanan (safety factor), dan posisi tegangan maksimum berada secara spesifik.

\subsection{Drag Force}

Gaya drag adalah gaya total yang diberikan oleh fluida pada bodi di dalam arah aliran karena efek gabungan dari gaya geser dinding dan tekanan. Bagian dari drag yang disebabkan langsung oleh tegangan geser dinding disebut friction drag dan bagian drag yang disebabkan oleh tekanan disebut dengan pressure drag. Friction drag dan pressure drag didefinisikan pada persamaan 1.

$$
C_{d, \text { friction }}=\frac{F_{d, \text { friction }}}{\frac{1}{2} \rho v^{2} A}
$$

$$
C_{d, \text { pressure }}=\frac{F_{d, \text { pressure }}}{\frac{1}{2} \rho v^{2} A}
$$

$$
\begin{array}{ll}
\text { dimana: } & \\
\mathrm{C}_{\mathrm{D}} & =\text { Koefisien drag } \\
\mathrm{F}_{\mathrm{D}} & =\text { Gaya drag }(\mathrm{N}) \\
\rho & =\text { Masa jenis udara }\left(\mathrm{kg} / \mathrm{m}^{3}\right) \\
\mathrm{V} & =\text { Kecepatan fluida }(\mathrm{m} / \mathrm{s}) \\
\mathrm{A} & =\text { Luas permukaan benda }\left(\mathrm{m}^{2}\right)
\end{array}
$$

\begin{tabular}{|c|c|c|c|c|}
\hline No. & Body & Laminar/Turbulent & Keterangan & CD \\
\hline 1 & Kubus & $\operatorname{Re}>10000$ & & 1,05 \\
\hline 2 & Lepeng lingkaran tipis & $\operatorname{Re}>10001$ & & 1,1 \\
\hline 3 & Kerucut $(\theta=30 \mathrm{o})$ & $\operatorname{Re}>10002$ & & 0,5 \\
\hline
\end{tabular}

Pada kasus plat datar yang yang memiliki posisi normal terhadap aliran, drag adalah hasil dari ketidakseimbangan distribusi tekanan. Untuk lebih jelasnya, besarnya koefisien drag dapat dilihat pada Tabel 1 berikut ini [11]:

Tabel 1. Koefisien drag pada bidang 3 Dimensi ( $\mathrm{L}=$ Panjang, $\mathrm{D}=$ Diameter) [aircraft perf analysis] 
$4 \quad$ Bola

$5 \quad$ Kapsul

6 Setengah lingkaran

$7 \quad$ Plat persegi

$8 \quad$ Silinder vertikal

$9 \quad$ Silinder horizontal

10 Parasut
Laminar $\operatorname{Re} \leq 2 \times 105$

Turbulent $R e \geq 2 \times 106$

Laminar $\operatorname{Re} \leq 2 \times 105$

Turbulent $\operatorname{Re} \geq 2 \times 106$

$\operatorname{Re}>10000$

$\operatorname{Re}>10001$

$\operatorname{Re}>10002$

$\operatorname{Re} \leq 2 \times 105$

$\operatorname{Re}>10001$

Laminar $\operatorname{Re} \leq 2 \times 105$

$\begin{array}{ll} & 0,5 \\ & 0,2 \\ & 0,3-0,5 \\ \text { Bagian cembung } & 0,1-0,2 \\ \text { Bagian datar } & 0,4 \\ \mathrm{~L} / \mathrm{D}=1 & 1,2 \\ \mathrm{~L} / \mathrm{D}=\infty & 1,1-1,3 \\ \mathrm{~L} / \mathrm{d}=0,5 & 0,6 \\ \mathrm{~L} / \mathrm{d}=8 & 1,2 \\ & 1,1 \\ & 1 \\ & 1,3\end{array}$

\subsection{Metode Mononobe}

Untuk perhitungan intensitas curah hujan digunakan rumus Mononobe pada persamaan 2:

$$
I=\frac{R_{24}}{24}\left(\frac{24}{t}\right)^{2 / 3}
$$

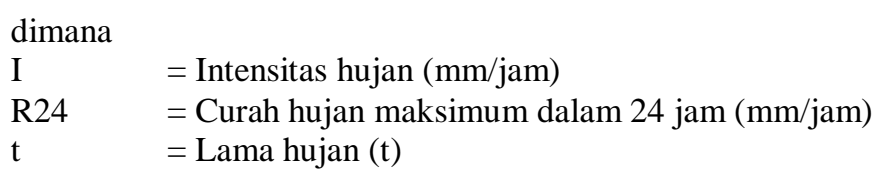

\subsection{Spesifikasi Papan Reklame}

Pada percobaan papan reklame untuk material yang digunakan adalah Baja ST37 dengan diameter tiang 14inch dan 40x4x4mm untuk dimensi siku pada frame papan reklame tersebut. Dengan kecepatan angin $15 \mathrm{~m} / \mathrm{s}$ dengan sudut tembak angin pada posisi $90^{\circ}$. Adapun papan reklame yang digunakan memiliki spesifikasi seperti terlihat pada Gambar 1 dan Tabel 2 serta Tabel 3.
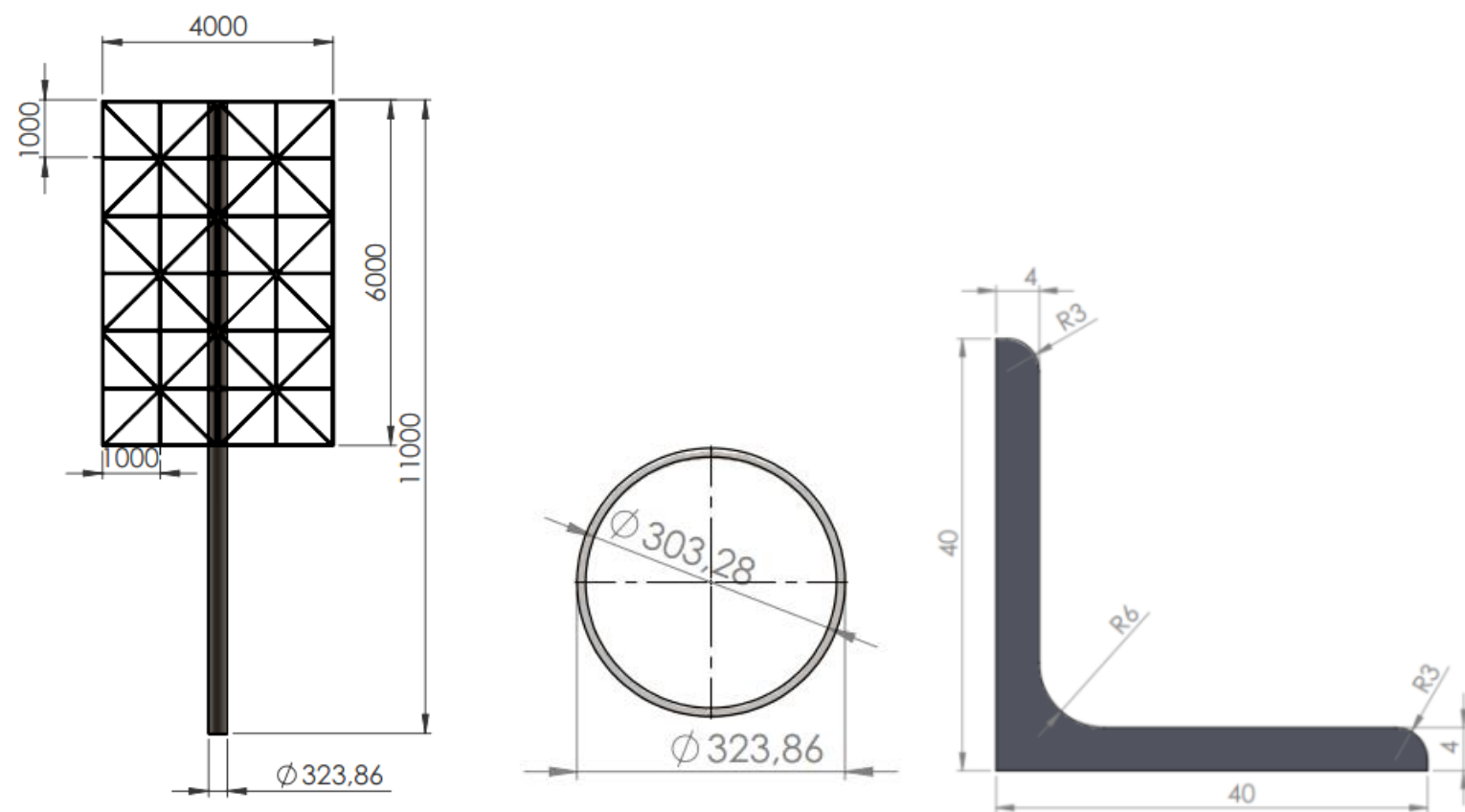

Gambar 1. Struktur papan reklame

Tabel 2. Tabel spesifikasi material dari struktur truss (ST37)

\begin{tabular}{ccccc}
\hline Yield Stress $(\mathrm{MPa})$ & Tensile Strength $(\mathrm{MPa})$ & Modulus Elasticity $(\mathrm{GPa})$ & Mass Density $\left(\mathrm{Kg} / \mathrm{m}^{3}\right)$ & Poisson's Ratio \\
\hline 235 & 360 & 210 & 7800 & 0.28
\end{tabular}

Tabel 3. Tabel spesifikasi material dari plat baja galvanis

\begin{tabular}{ccccc}
\hline Yield Stress $(\mathrm{MPa})$ & Tensile Strength $(\mathrm{MPa})$ & Modulus Elasticity $(\mathrm{GPa})$ & Mass Density $\left(\mathrm{Kg} / \mathrm{m}^{3}\right)$ & Poisson's Ratio \\
\hline 204 & 357 & 200 & 7870 & 0.29
\end{tabular}




\subsection{Penetapan Pembuatan Enclosure dan Menentukan Ukuran Mesh}

Pembuatan enclosure dibuat sesuai dengan metode ahmed's body. Namun untuk sekaligus mempelajari pola aliran yang dibentuk, panjang wind tunnel dibuat 2 kali lipat dari ketentuan. Dimensi enclosure adalah 4L untuk tinggi enclosure, 4L untuk lebar enclosure, dan 16L untuk panjang enclosure dengan L adalah tinggi billboard, yaitu $6 \mathrm{~m}$. Kondisi batas pada tiap sisi enclosure seperti dijelaskan pada Tabel 4 dan divisualkan pada Gambar 2.

Tabel 4. Kondisi batas enclosure

\begin{tabular}{cc}
\hline Jenis kondisi batas & Sisi enclosure \\
\hline Inlet & Sisi pada sumbu - Z didepan muka billboard \\
Outlet & Sisi pada sumbu + Z dibelakang muka billboard \\
Sym & Bagian atas, sisi kiri dan kanan billboard \\
Wall & Seluruh sisi billboard dan bagian bawah enclosure \\
\hline
\end{tabular}

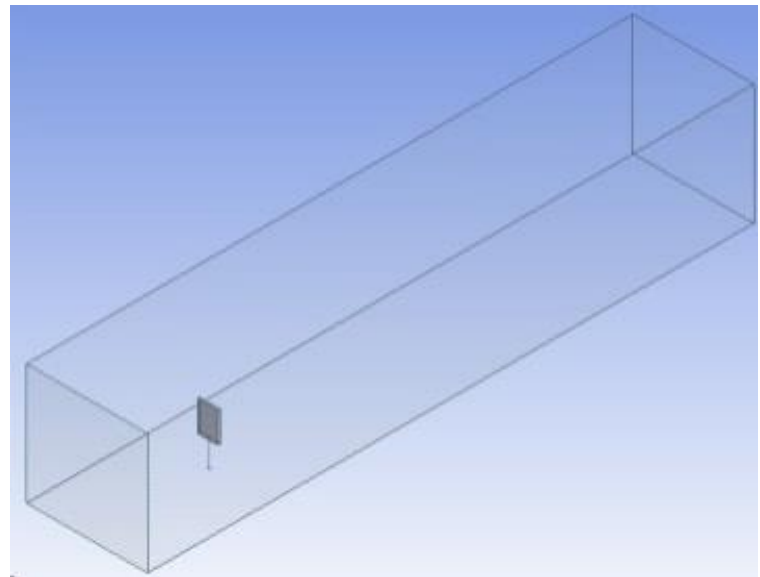

Gambar 2. Enclosure udara untuk simulasi

Meshing untuk enclosure didapat dengan memberikan ukuran yang tepat untuk menghasilkan meshing dengan skewness yang baik, yaitu $\leq 80$. Pengaturan konfigurasi mesh seperti tercantum pada Tabel 5.

Tabel 5. Konfigurasi mesh

\begin{tabular}{cc}
\hline Jenis Konfigurasi & Konfigurasi \\
\hline Use Advanced Size Function & On proximity and curvature \\
Relevance Center & Fine \\
Smoothing & High \\
Transition & Slow \\
Curvature Normal Angle & $12^{\circ}$ \\
Num Cells Across Gap & 5 \\
\hline
\end{tabular}

Kemudian, berikan face sizing pada permukaan billboard sebesar 20mm utnuk meningkatkan keakurasian perhitungan pada seluruh sisi papan reklame. Hasil yang didapat dari konfigurasi tersebut adalah mesh dengan skewness maksimum 0,797330917591936 seperti pada Gambar 3.

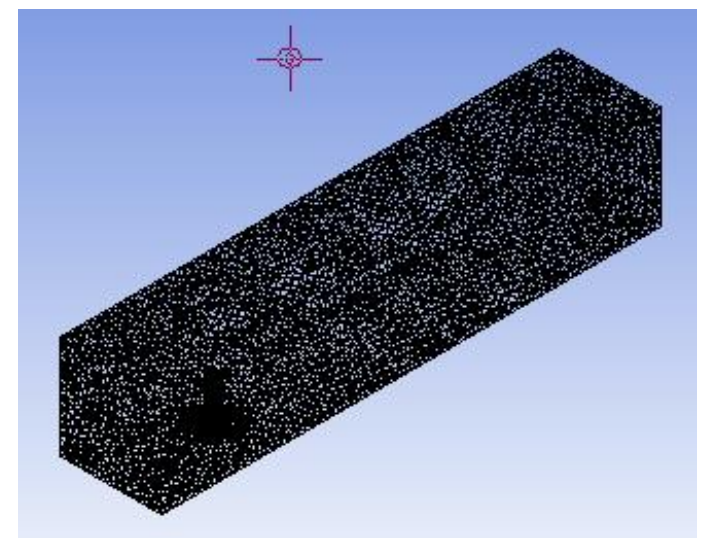

(a)

\begin{tabular}{|l|l|}
\hline Statistics & \\
\hline$\square$ Nodes & 888459 \\
\hline$\square$ Elements & 4830140 \\
\hline Mesh Metric & Skewness \\
\hline$\square$ Min & $1,73862761566612 \mathrm{E}-05$ \\
\hline$\square$ Max & 0,797330917591936 \\
\hline$\square$ Average & 0,233720729367323 \\
\hline$\square$ Standard Deviation & 0,120400884883659 \\
\hline \hline
\end{tabular}

(b)

Gambar 3. (a) Hasil mesh dan (b) ukuran statistik mesh 


\section{Hasil dan pembahasan}

\subsection{Simulasi Hujan Angin Pada Struktur}

Untuk mencari besaran gaya akibat air hujan, digunakan kondisi batas seperti pada Tabel 6.

Tabel 3.1 Tabel sifat air hujan

\begin{tabular}{ll}
\hline Parameter & Nilai \\
\hline$v_{\text {angin }}$ & $15 \mathrm{~m} / \mathrm{s}$ \\
$\dot{m}$ & $0.070877 \mathrm{~kg} / \mathrm{s}$ untuk setiap $1 \mathrm{~m}^{2}$ area hujan \\
$\mathrm{T}$ & $25^{\circ} \mathrm{C}$ \\
$\rho$ & $1000 \mathrm{~kg} / \mathrm{m}^{3}$ \\
$\mu_{\text {droplet }}$ & $0,89 \mathrm{~kg} / \mathrm{ms}$ \\
$\sigma_{\text {droplet }}$ & $0,07197 \mathrm{n} / \mathrm{m}$ \\
$D_{\text {droplet }}$ & $1-5 \mathrm{~mm}$ \\
\hline
\end{tabular}

Simulasi dilakukan menggunakan software ANSYSTM FLUENT dengan menggunakan data pada Tabel 6 . Udara digunakan sebagai material pengisi enclosure. Untuk memodelkan aliran, digunakan pemodelan viscous k-epsilon realizable dengan scallable wall function untuk near-wall treatment. Sedangkan untuk mensimulasikan droplet-nya, digunakan pemodelan Discreet Phase Modelling (DPM) dengan continuous phase dan stochastic collision serta coalescent aktif pada tab physical models. Kondisi droplet air hujan diinjeksikan pada pemodelan DPM. Hasil yang didapat dari simulasi aliran seperti terlihat pada Gambar 4 dan 5.

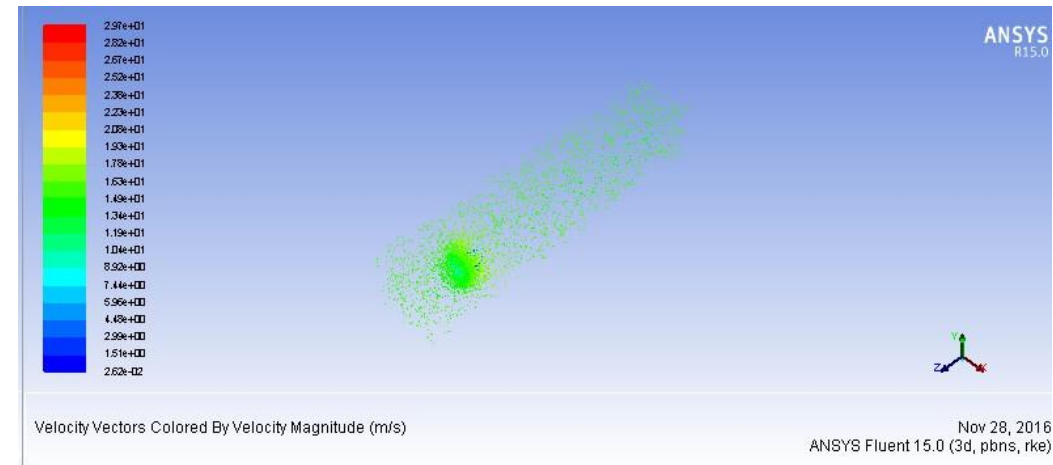

Gambar 4. Persebaran kecepatan droplet

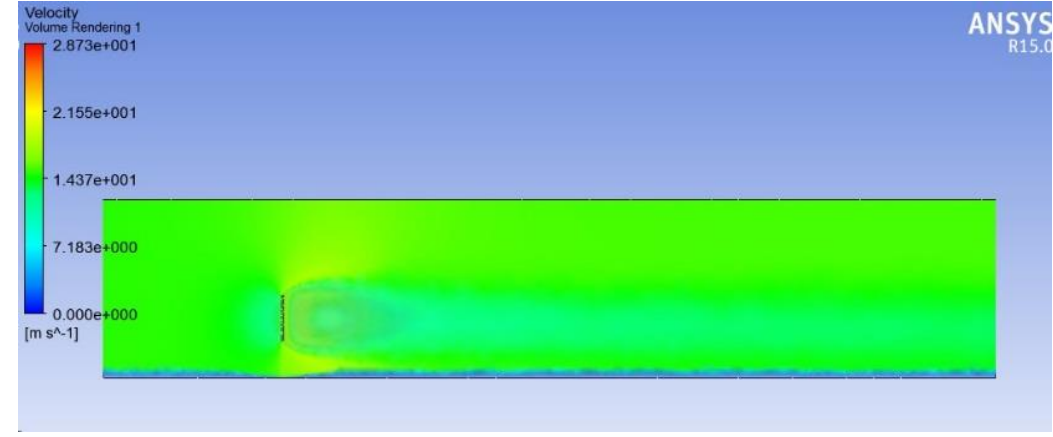

Gambar 5. Pola kecepatan aliran

\begin{tabular}{|c|c|c|c|}
\hline $\begin{array}{l}\text { Forces - Direction Uector } \\
\text { Zone } \\
\text { billboardplate } \\
\text { billboardstructure } \\
\text { earth }\end{array}$ & $\begin{array}{l}(0,-1) \\
\text { Forces (n) } \\
\text { Pressure } \\
2701.2813 \\
1712.9933 \\
6\end{array}$ & $\begin{array}{l}\text { Uiscous } \\
\text { B } \\
3.4620152 \\
713.91839\end{array}$ & $\begin{array}{l}\text { Total } \\
2701.2813 \\
1716.4553 \\
713.91899\end{array}$ \\
\hline Net & 4414.2745 & 717.38011 & 5131.6546 \\
\hline
\end{tabular}

Gambar 6. Gaya yang dihasilkan oleh hujan angin

\subsection{Simulasi Pembebanan Statis Pada Struktur}

Metode pembebanan yang digunakan adalah metode pembebanan statis pada Solidwork's simulation. Beban yang digunakan adalah drag force yang terjadi pada aliran angin yang bercampur butiran air hujan yang nilainya $4414,3 \mathrm{~N}$ seperti pada Gambar 6. Sedangkan bentuk meshing adalah based curvatured dan ukuran meshing 10mm dan 0,2mm Hasil yag didapat dari simulasi pembebanan statis adalah nilai stress, displacement, dan strain dari struktur, seperti pada Gambar 7 hingga 9 berikut ini: 


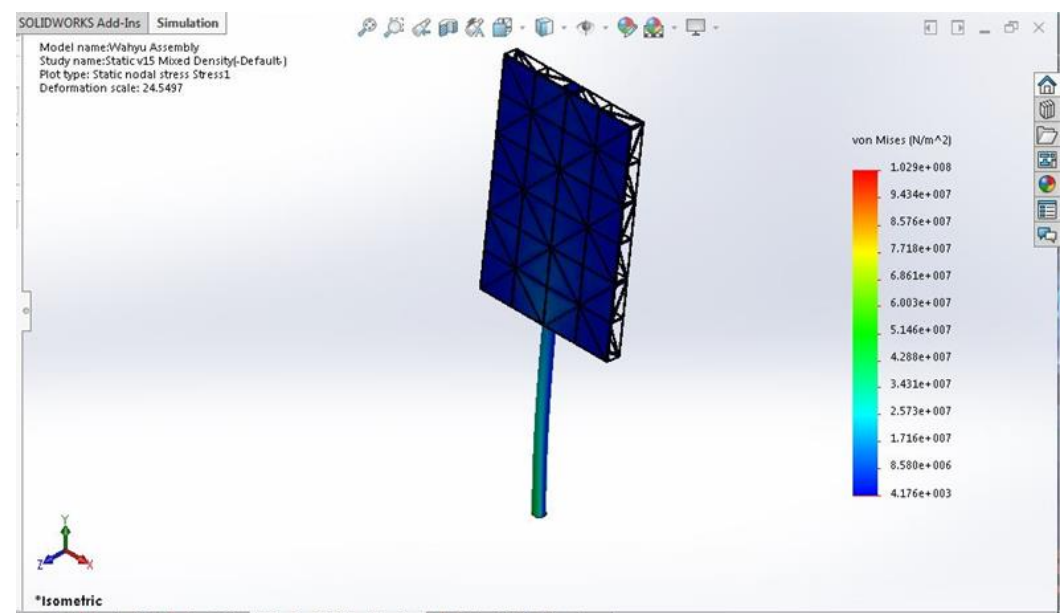

Gambar 7. Nilai stress maksimum pada struktur setelah diberi beban

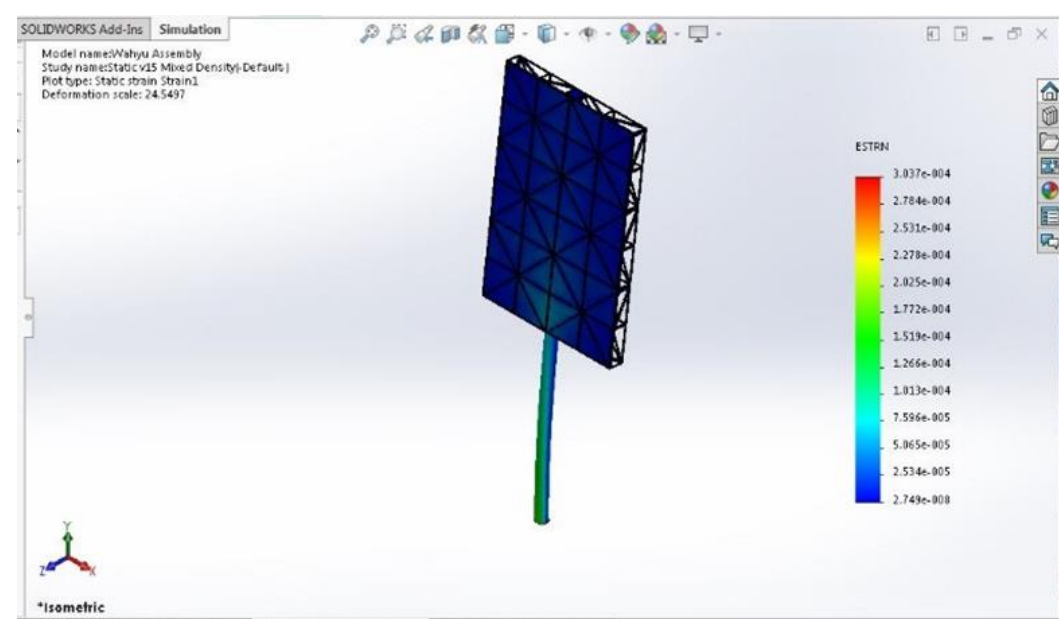

Gambar 8. Nilai strain maksimum pada struktur setelah diberi beban

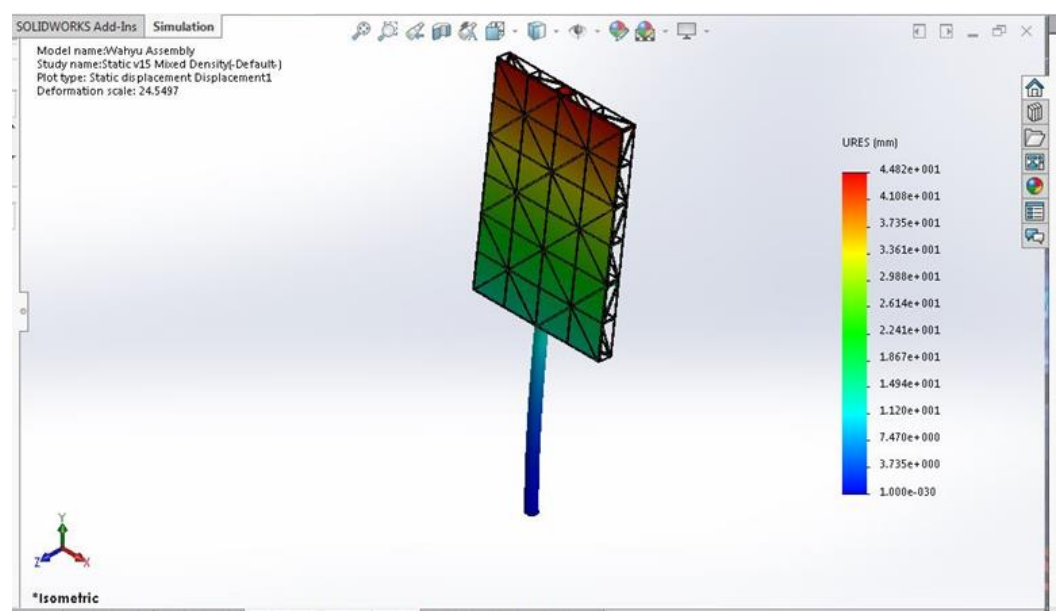

Gambar 9. Nilai displacement maksimum pada struktur setelah diberi beban

Menurut Peraturan Pembangunan di indonesia tahun 1983 untuk suatu bangunan yang mengalami beban angin, kecepatan angin yang digunakan adalah $25 \mathrm{~m} / \mathrm{s}$. Dengan metode yang sama, pada Tabel 7 disajikan perbandingan antara gaya akibat hembusan angin dan gaya akibat hujan angin pada struktur untuk masing - masing kecepatan $(15 \mathrm{~m} / \mathrm{s}$ dengan massa jenis $1,225 \mathrm{~kg} / \mathrm{m}^{3}$ dan $25 \mathrm{~m} / \mathrm{s}$ dengan massa jenis $1,2297 \mathrm{~kg} / \mathrm{m}^{3}$ )

Tabel 7. Hasil Pembebanan Statik dengan SolidWorks

\begin{tabular}{lcccc}
\hline \multicolumn{1}{c}{ Parameter } & \multicolumn{3}{c}{ Nilai } \\
\hline Massa jenis & $1,225 \mathrm{~kg} / \mathrm{m}^{3}$ & $1,225 \mathrm{~kg} / \mathrm{m}^{3}$ & $1,2297 \mathrm{~kg} / \mathrm{m}^{3}$ & $1,2297 \mathrm{~kg} / \mathrm{m}^{3}$ \\
Kecepatan aliran & $15 \mathrm{~m} / \mathrm{s}$ & $25 \mathrm{~m} / \mathrm{s}$ & $15 \mathrm{~m} / \mathrm{s}$ & $25 \mathrm{~m} / \mathrm{s}$ \\
\hline
\end{tabular}




\begin{tabular}{lcccc}
\hline Gaya pada struktur & $4414,2 \mathrm{~N}$ & $11851,2 \mathrm{~N}$ & $4430,3 \mathrm{~N}$ & $11896,0 \mathrm{~N}$ \\
Stress maksimal & $1,025 \times 10^{8} \mathrm{~Pa}$ & $2,754 \times 10^{8} \mathrm{~Pa}$ & $1,029 \times 10^{8} \mathrm{~Pa}$ & $2,762 \times 10^{8} \mathrm{~Pa}$ \\
Strain maksimal & $3,024 \times 10^{4} \mathrm{~Pa}$ & $8,1260 \times 10^{4} \mathrm{~Pa}$ & $3,037 \times 10^{4} \mathrm{~Pa}$ & $8,156 \times 10^{4} \mathrm{~Pa}$ \\
Displacement max. & $44,62 \mathrm{~mm}$ & $119,99 \mathrm{~mm}$ & $44,82 \mathrm{~mm}$ & $120,30 \mathrm{~mm}$ \\
\hline
\end{tabular}

\section{Kesimpulan}

Dari hasil simulasi dengan ANSYS dan solidworks didapatkan nilai stress maksimal 1,025 x $10^{8}$ Pa pada kecepatan angin $15 \mathrm{~m} / \mathrm{s}$, dan $2,754 \times 10^{8} \mathrm{~Pa}$ pada kecepatan angin $25 \mathrm{~m} / \mathrm{s}$ untuk kondisi pembebanan berupa angin. Sedangkan nilai stress maksimal $1,029 \times 10^{8} \mathrm{~Pa}$ pada kecepatan angin $15 \mathrm{~m} / \mathrm{s}$, dan $2,762 \times 10^{8} \mathrm{~Pa}$ pada kecepatan angin $25 \mathrm{~m} / \mathrm{s}$ untuk kombinasi beban angin serta curah hujan. Kedua nilai tegangan maksimum untuk kecepatan angin $15 \mathrm{~m} / \mathrm{s}$ yang didapat masih dibawah yield strength dari material pembentuk struktur, yaitu $235 \mathrm{MPa}$. Sehingga struktur aman digunakan pada kondisi pembebanan tersebut. Namun pada kecepatan $25 \mathrm{~m} / \mathrm{s}$, tegangan maksimum berada pada \pm 30 Mpa diatas yield strength, artinya struktur tidak aman apabila mengalami beban sebesar itu secara terus menerus dan riskan oleh tegangan fatigue. Hasil pengujian menunjukkan gaya akibat air hujan pada struktur tidak terlalu signifikan. Besarnya selisih gaya antara gaya drag hujan dengan gaya drag air dan hujan selalu lebih kecil dari $50 \mathrm{~N}$. Sehingga untuk perhitungan secara umum, besarnya gaya akibat air hujan bisa diabaikan.

\section{Daftar Pustaka}

[1] http://news.detik.com/berita/d-1869270/-braak-papan-reklame-roboh-timpa-warnet-di-semarang, diakses pada tanggal 10 November 2016.

[2] http://www.pikiran-rakyat.com/bandung-raya/2013/03/27/228628/lima-papan-reklame-roboh-saat-hujan-deras, diakses pada tanggal 10 November 2016.

[3] http://transvertising.com/news.php?title=4_kendaraan_tertimpa_baliho_raksasa_yang_roboh_di_slipi, diakses pada tanggal 10 November 2016.

[4] Peraturan Daerah Kota Semarang no. 14 Tahun 2012 Tentang Penyelenggaran Reklame.

[5] An, S., 2009. Wind Disaster Vulnerability Study of Single-column Billboard Structure. Ph.D. Dissertation. Harbin Institute of Technology, Harbin, China (In Chinese).

[6] Tamura, Y., Cao, S., 2009. Climate change and wind-related disaster risk reduction. In:Proceedings of the APCWE-VII, Taipei, Taiwan.

[7] Song, F., Ou, J., 2009. Study on the dynamic causes of damage of large billboard by typhoon. In: 14th National Conference of Structural Wind Engineering, Beijing (In Chinese).

[8] Wang, X., Cheng, J., Wang, Q., 2010. The causes analysis and counter measures of billboard collapse under the strong wind load. Construction \& Design for Project 11, 47-51 (In Chinese).

[9] Li, Z., Wang, D., Chen, X., Liang, S., Li, J., 2018. Wind load effect of single-column-supported two-plate billboard structures. Journal of Wind Engineering \& Industrial Aerodynamics 179: 70-79.

[10] BMKG Kota Semarang, 2016, "Data Kecepatan Angin dan Curah Hujan Maksimum Bulanan Tahun 2010-2015", BMKG, Semarang.

[11] Sadraey M., 2009, “Aircraft Performance Analysis”, VDM Verlag Dr. Müller, Berlin. 